\title{
MESMO QUE CAPITUTENHA TRAIIDO DOM CASMURRO: UMA ANÁLISE COMPARATIVA ENTRE O ROTEIRO DE PAULO EMÍLIO SALES GOMES E LYGIA FAGUNDES TELLES E O ROMANCE DE MACHADO DE ASSIS $^{6}$

\author{
EVEN IF CAPITU HAS BETRAYED DOM CASMURRO: A \\ COMPARATIVE ANALYSIS BETWEEN THE SCREENPLAY \\ TELLES AND THE NOVEL OF MACHADO DE ASSIS
} OF PAULO EMÍLIO SALES GOMES AND LYGIA FAGUNDES
}

Danielle Rasmussen Betemps ${ }^{7}$

Resumo: Este artigo é o resultado de uma análise comparativa entre o roteiro cinematográfico Capitu (1967), de Paulo Emílio Sales Gomes e Lygia Fagundes Telles, e o romance Dom Casmurro (1900), de Machado de Assis. Considerando o roteiro como uma primeira adaptação, a referida análise visou contestar a ideia de fidelidade e a consequente desvalorização das adaptações cinematográficas. Para tanto, partiu-se da secular relação entre cinema e literatura, mais estritamente das diferenças e semelhanças entre os textos literário e cinematográfico, enfocando as características de dois elementos ficcionais - narrador e personagem - e as estratégias utilizadas por ambos os sistemas no processo de configuração desses elementos. Ilustraram-se acréscimos feitos no roteiro, discutiu-se a função do narrador-protagonista do romance e as estratégias utilizadas no roteiro para sua representação e refletiu-se acerca das escolhas feitas pelos roteiristas para a elaboração de Capitu. Concluiu-se que os roteiristas

\footnotetext{
${ }^{6}$ Trata-se, originalmente, de Trabalho de Conclusão de Curso orientado pelo Prof. Dr. João Luis Pereira Ourique e apresentado ao Centro de Letras e Comunicação da Universidade Federal de Pelotas, como requisito parcial à obtenção do titulo de Bacharel em Letras - Redação e Revisão de Textos.

${ }^{7}$ Mestranda no Programa de Pós-Graduação em Letras - Literatura Comparada: Estudos de Intertextualidade da Universidade Federal de Pelotas (UFPel). E-mail: dani.betemps@gmail.com
} 


\section{6 | Danielle Rasmussen Betemps}

adicionaram elementos que inexistem no texto literário com a finalidade de adaptar o romance aos limites do texto cinematográfico, mas sem deixar de apontar para o texto machadiano. Quanto à narração, foi constatado que a focalização recai no protagonista Bentinho, o qual é perseguido pelo roteiro - que mostra o que ele vê e como vê. Essas alterações configuram escolhas dos roteiristas, as quais foram feitas durante o processo de escrita do roteiro para melhor moldar o texto literário de Machado de Assis a outro texto: o cinematográfico.

Palavras-chave: Literatura. Cinema. Adaptação. Roteiro.

Abstract: This paper is the result of a comparative analysis between the screenplay Capitu (1967), of Paulo Emilio Sales Gomes and Lygia Fagundes Telles, and the novel Dom Casmurro (1900), of Machado de Assis. Considering the screenplay as a first adaptation, this analysis aimed to challenge the idea of fidelity and the consequent devaluation of the film adaptations. So, we started from the secular relationship between cinema and literature, more closely the differences and similarities between literary and cinematic texts, focusing on the characteristics of two fictional elements - narrator and character - and the strategies used by both systems in the process of configuration of these elements. Thus were illustrated additions made in the screenplay, discussed the role of the narrator-protagonist in the novel and the strategies used in the screenplay for their representation, also, was thought about the choices made by the writers in order to elaborate Capitu. It was concluded that the writers added elements that doesn't exist in the literary text in order to adapt the novel to the limits of the cinematic text, but still making references to Machado's text. Regarding the cinematic narrator, it was found that the focus lies in the protagonist Bentinho, which is pursued by the screenplay - which shows what he sees and how he sees. These changes configure the writers' choices, which were made during the process of writing the screenplay to better shape the literary text by Machado de Assis into an another text: the cinematic.

Keywords: Literature. Cinema. Adaptation. Screenplay. 
A partir da invenção dos irmãos Lumière - o cinematógrafo, cuja primeira apresentação pública ocorreu em dezembro de 1895, na cidade de Paris - e da consequente relação entre cinema e literatura, o fazer literário sofreu várias mudanças. Os autores passaram a incluir em suas obras mecanismos fílmicos com o intuito de alcançar a impressão de realidade, muito marcada nos filmes. Por outro lado, os cineastas viram na literatura um vasto acervo de conteúdo para suas produções. Assim, a secular relação entre o literário e o cinematográfico, a qual se estabeleceu naturalmente nos primórdios da sétima arte, rendeu uma série de empréstimos mútuos.

No entanto, há quem não concorde com essa relação interartes e considere as adaptações fílmicas como empobrecedoras das obras adaptadas. Na década de 20, muitos teóricos e cineastas defendiam uma forma "pura" de fazer cinema, isto é, acreditavam nas especificidades próprias de uma arte cinematográfica totalmente livre de influências vindas das artes "mais velhas", anteriores a ela.

Além disso, o roteiro adaptado - por ser um suporte menor em extensão que um romance, por exemplo - também acaba sendo menosprezado por muitos leitores, que avaliam a qualidade dos filmes de acordo com sua (in)fidelidade em relação às obras que retratam - um conceito falho, uma vez que literatura e cinema são campos de linguagens distintas. Entretanto, as distinções sistemáticas existentes entre o texto literário e sua adaptação não costumam ser evidenciadas na maioria dos trabalhos sobre o assunto, os quais geralmente se detêm na análise da transposição do plano de expressão (palavra) ao plano de conteúdo (imagem) e, com isso, acabam desconsiderando o elemento mediador $\mathrm{e}$ primordial desses dois planos: o roteiro.

Objetiva-se, aqui, contestar a ideia de fidelidade comumente exigida pelos espectadores que leram o texto "original" antes de assistir ao filme que o retrata - e a consequente desvalorização das adaptações cinematográficas - a qual deriva de uma série de preconceitos que, segundo Robert Stam (2006, p. 21), podem ser resumidos em seis termos: antiguidade, pensamento 


\section{8 | Danielle Rasmussen Betemps}

dicotômico, iconofobia, logofilia, anti-corporalidade e carga de parasitismo, os quais serão retomados posteriormente neste artigo.

A fim de refutar esses rótulos de inferioridade postos nas adaptações, iremos partir da relação entre cinema e literatura, mais estritamente das diferenças e semelhanças entre os textos literário e cinematográfico, enfocando as características de dois elementos ficcionais - narrador e personagem - e as estratégias utilizadas por ambos os sistemas no processo de configuração desses elementos. Para tanto, serão utilizados o romance Dom Casmurro, de Machado de Assis (edição anotada da Coleção L\&PM POCKET, datada de junho de 2011), e o roteiro Capitu, de Paulo Emílio Sales Gomes e Lygia Fagundes Telles (edição de 2008, publicada pela editora Cosac Naify, que inclui posfácio de Lygia Fagundes Telles e apêndice de Augusto Massi).

A partir desses dois objetos de análise, pretende-se ilustrar acréscimos, isto é, conteúdos que não aparecem explicitamente no romance, mas foram expressos no roteiro - partindo da ideia de que tais acréscimos caracterizam esse gênero textual. Além disso, serão discutidas também a função do narrador-protagonista do romance e as estratégias cinematográficas utilizadas na adaptação para a representação desse narrador. E, por fim, iremos refletir acerca das escolhas feitas pelos roteiristas para a elaboração de Capitu.

Este trabalho, portanto, considerará o roteiro como o estopim do processo adaptativo, isto é, a primeira adaptação, antes mesmo do filme adaptado. Considerando, ainda, a concepção de que "o roteiro é o momento em que realmente as coisas acontecem” (FURTADO, 2001 apud AVELLAR, 2007, p. 124), colocar-se-ão os dois objetos de análise em níveis diferentes, mas não hierarquizados, de produção criativa.

Desde o seu nascimento, em 1895, a sétima arte - que ainda é "jovem", se comparada às outras seis - já foi teorizada de diversas formas. Entre as décadas de 1920 e 1930, cineastas pertencentes ao movimento avant-garde da cultura europeia lutaram pelo cinéma pur, que "pretendia proteger o cinema da literatura, favorecendo a autonomia de sua medialidade, da mesma forma que a literatura já 
havia condenado tacitamente a transposição fílmica" (PAECH, 2013, p. 54). Assim, o caráter comercial da indústria fílmica era repudiado ao mesmo tempo em que a ausência de influências de outras artes, principalmente a literatura, no fazer cinematográfico era defendida. Acreditava-se em um cinema calcado nas suas próprias especificidades e destituído de qualquer conexão com as demais manifestações artísticas - incluindo as narrativas romanescas ou teatrais, por exemplo.

Contrário a essa homogeneidade cinematográfica, em meados da década de 1950, André Bazin lança o termo cinéma impur, a partir do qual defende o caráter híbrido do cinema e mostra-se favorável às adaptações. Diz ele:

O cinema é jovem, mas a literatura, o teatro, a música, a pintura são tão velhos quanto a história. Do mesmo modo que a educação de uma criança se faz por imitação dos adultos que a rodeiam, a evolução do cinema foi necessariamente inflectida pelo exemplo das artes consagradas (BAZIN, 1991, p. 84).

Para Bazin (1991, p. 84), seria impossivel que o cinema escapasse ileso às influências das artes mais antigas e que a adaptação, apesar de desprestigiada pela redoma crítica da época, "é uma constante da história da arte". Assim, pode-se pensar o cinema como uma manifestação iniciante, a qual buscou moldar paulatinamente suas especificidades, partindo dos estatutos de suas antecessoras.

Entretanto, como já foi salientado na introdução deste trabalho, a relação entre literatura e cinema é perpassada por empréstimos mútuos, ou seja, se a literatura "educou" a sétima arte, essa também exerceu forte influência no processo de reformulação daquela.

Os romances do século XX, em meio a uma renovação da escrita literária, visaram à impressão de realidade produzida pelos filmes, pois, segundo Christian Metz (2010, p. 16), numa paráfrase de Albert Laffay, "mais do que o romance, mais do que a peça de teatro, mais do que o quadro do pintor figurativo, o filme nos dá o 


\section{0 | Danielle Rasmussen Betemps}

sentimento de estarmos assistindo diretamente a um espetáculo quase real". Isso ocorre devido ao movimento exercido pela câmera do filme que, dentre outras coisas, confere aos objetos e personagens uma espécie de "materialidade", da qual surgirá a impressão de realidade, que, por sua vez, irá desencadear fenômenos de participação, afeição, repulsa, percepção crítica, etc.

Assim, ao se firmar como arte legítima, o cinema passou a ser visto como a melhor forma de ilustrar a vida urbana moderna em meio ao seu ritmo acelerado, aos avanços das reproduções técnicas e ao modo industrial de produção artística, e, valendo-se de recursos cinematográficos, os escritores modernos buscaram efeitos - como o da simultaneidade, por exemplo - para alforriar o texto literário, que, até o momento, era escravo da sequência linear (FIGUEIREDO, 2010, p. 25).

Houve outros casos em que a literatura dialogou com o cinema. Os romances da série noir poderiam ser vistos como "roteiros cinematográficos ampliados" (FIGUEIREDO, 2010, p. 17) e, segundo Bazin (1991, p. 82), foram "escritos com dupla finalidade e em vista de uma possivel adaptação por Hollywood”. A publicação do roteiro L'Année dernière à Marienbad, de Alain Resnais, em 1961, influenciou o nouveau roman, cuja característica central era provocar no leitor, a partir de configurações literárias, efeitos comumente proporcionados por imagens (FIGUEIREDO, 2010, p. 17).

No Brasil, esse diálogo pode ser identificado no "romance cinematográfico" de Mário de Andrade, datado de 1927: Amar, verbo intransitivo. Segundo Avellar (2007, p. 62), o livro segue tão estritamente a montagem cinematográfica, a ideia de fragmento e o ritmo ágil, que parece ser exposto como um filme e, por isso, o leitor "é convidado a ler como se fosse um espectador de cinema", ou seja, a narrativa literária é cinematográfica em sua distribuição.

Outro exemplo brasileiro é Vidas Secas, cuja transposição às telas, em 1963, foi feita pelo paulista Nelson Pereira dos Santos. O diretor e roteirista disse, em entrevista publicada na Revista IBM no ano de 1984, que o romance de Graciliano Ramos "é tão rico em imagens, os detalhes são tão surpreendentes, que já é uma espécie 
de roteiro" (AVELLAR, 2007, p. 47). A equiparação de Vidas Secas a um roteiro nos remete à ideia de que a obra de arte nasce para ser reproduzida (BENJAMIN, 1986, p. 171) e que essa reprodução pode estar sujeita a uma variedade de meios - sejam eles literários ou cinematográficos.

Considerando toda a influência que o cinema acarretou à literatura, pode-se pensar, então, numa repartição da literatura entre antes e depois do cinematógrafo. Mas concluir apenas que a arte cinematográfica é posterior à literária não implica sua colocação "atrás" da literatura em um ranking sobre "valor" cultural - mesmo que tal pensamento tenha vigorado entre os intelectuais conservadores enquanto o cinema se tornava popular e o teatro só atingia uma minoria rica e selecionada.

O desprestígio sofrido pelas adaptações cinematográficas, mesmo que cadenciado, perdurou até a atualidade. Robert Stam (2006) elenca, em um artigo traduzido e publicado na revista Iha do Desterro, seis termos que resumem esse preconceito e que já foram elucidados na introdução deste artigo.

O primeiro é o pressuposto da antiguidade, que preconiza as artes antigas como necessariamente artes melhores; o segundo, pensamento dicotômico, é o pressuposto de que o ganho do cinema resulta em perdas para a literatura; a iconofobia, terceiro termo elencado, significa o preconceito contra as artes visuais; já o quarto termo, logofilia, constitui uma valorização típica de culturas seguidoras da "religião do livro"; a anticorporalidade, quinto termo que resume o preconceito sofrido pelas adaptações, é o desgosto pela concretização do texto literário, ou seja, pela transformação dos personagens em seres de carne e osso; e, por fim, a carga de parasitismo, que é a visão duplamente "menos" que se tem das adaptações cinematográficas - as quais são tratadas como menos que um romance, por ser uma cópia, e menos que um filme, por não ser um filme puro e original (STAM, 2006, p. 21).

A todos esses termos é possível juntar o receio de substituição, pois se a litografia foi muito rapidamente substituída pela fotografia (BENJAMIN, 1986, p. 167), a adaptação também teria o poder de substituir o romance, conto, poema adaptado. $\mathrm{O}$ 


\section{2 | Danielle Rasmussen Betemps}

leitor teme que sua obra favorita desvaneça devido à adaptação fílmica e então não considera que, ao contrário da fotografia, o cinema não intenta aperfeiçoar o que está adaptando, mas apenas criar - ou transcriar, como sugere Julio Plaza ${ }^{8}$ - algo novo e diferente a partir disso.

Trata-se do conceito de hipertextualidade proposto por Genette (1989, p. 14), cuja compreensão está calcada em todas as relações possiveis que possam associar um texto (B - hipertexto) a outro (A - hipotexto), esse anterior àquele. Além desse, Genette elenca outros quatro tipos de transtextualidade: intertextualidade, paratextualidade, metatextualidade e arquitextualidade? . Para Stam (2006, p. 33, grifo nosso), todos os tipos transtextuais conversam com a teoria da adaptação, mas o da hipertextualidade apresenta maior relevância para o estudo, já que as adaptações cinematográficas "são hipertextos derivados de hipotextos préexistentes que foram transformados por operações de seleção, amplificação, concretização e efetivação” e, assim, mostram como, na prática, o conceito de Genette é aplicado.

A visão preconceituosa de que a adaptação, enquanto "cópia”, é inferior ao "original" por não retratá-lo com a devida "sequência de fidelidade" é outro aspecto que diz respeito à díade cinema-literatura e que deve ser repensado, pois "a insistência na 'fidelidade' - que deriva das expectativas que o espectador traz ao filme, baseadas na sua própria leitura do original - é um falso problema porque ignora diferenças essenciais entre os dois meios" (JOHNSON, 2003, p. 42).

Além disso, a própria hierarquização de "original" e "cópia" pode ser contestada. Stam (2006, p. 22) traz à luz o Desconstrutivismo, representado pelo filósofo francês Jacques Derrida, para afirmar que essa corrente ajudou a desfazer

8 A transcriação apresentada pelo autor ocorre quando uma tradução intersemiótica se preocupa menos em ser o "original" em outro sistema de signos que em criar similaridades que a remetam a esse "original". Assim, "traduzir com invenção pressupõe reinventar a forma, isto é, aumentar a informação estética" (PLAZA, 2010, p. 98) e não assumir o lugar dela.

${ }^{9}$ Cf. GENETTE, 1989, p. 10-14. 
"binarismos excessivamente rígidos" como, por exemplo, original versus cópia - ou seja, "numa perspectiva derridiana, o prestígio aural $^{10}$ do original não vai contra a cópia, mas é criado pelas cópias, sem as quais a própria ideia de originalidade perde o sentido”, uma vez que o original existe em função de haver uma ou mais cópias suas. Em suma, pode-se dizer que as adaptações legitimam a originalidade do que adaptam.

No livro Tradução Intersemiótica, de Julio Plaza (2010), é possivel o contato com exemplos de traduções de sistemas diversos - o que possibilita a compreensão dos processos da tradução intersemiótica ${ }^{11}$ e a contestação da ideia de fidelidade obrigatória da tradução para com a obra traduzida. Com os exemplos trazidos por esse autor, fica claro que a passagem de um sistema de signos para outro sistema implica o afugentamento da exigência de que a adaptação seja igual ao adaptado. Assim, Plaza (2010, p. 32-33) trata a ideia de fidelidade como uma questão ideológica, já que "mesmo o processo pretendidamente mimético caracteriza-se pelo fato de algo tentar fazer-se igual a outro, mostrando-se como nãoigual”.

Pode-se pensar, então, que é nesse "mostrando-se como nãoigual”, trazido por Plaza (2010), que encontramos as características próprias do cinema - o qual se vale de narrativas literárias para a construção de roteiros adaptados.

A concepção de gênero literário teve na República de Platão uma de suas primeiras formulações, a qual se inicia com a distinção, baseada no ritmo das narrativas, entre prosa e poesia. Mais tarde, Aristóteles propôs a categorização da produção literária de acordo com a estória, designando os gêneros que conhecemos até hoje como dramático, lírico e épico. Esse último, também chamado de narrativo, é caracterizado pelo uso de narrações, descrições e diálogos na composição das estórias. Além disso, o gênero épico engloba, assim como os outros dois gêneros, subdivisões

\footnotetext{
${ }^{10}$ Cf. BENJAMIN, 1986, p. 167-170, a respeito do conceito de aura.

${ }^{11}$ Definida por Diniz (1998, p. 313) como "tradução de um determinado sistema de signos para outro sistema semiótico".
} 


\section{4 | Danielle Rasmussen Betemps}

conhecidas como espécies literárias. Dentre as espécies narrativas, destaca-se o romance, o qual se caracteriza pela presença de elementos como tempo, espaço, ambiente, estilo, tema, personagens e narrador - sendo do nosso interesse os métodos de utilização desses dois últimos elementos.

Existem inúmeras formas de caracterizar um personagem romanesco. No capítulo sobre gênero de ficção das Notas de teoria literária, Afrânio Coutinho (2008, p. 52-55) parte do volume qualitativo que caracteriza os personagens (individual, típico ou caricatura), passa pelo fator da função que esses exercem na estória (protagonista, antagonista, secundário, confidente, de contraste ou narrador), considera os personagens quanto a sua universalidade $e^{12} \mathrm{e}$ finaliza com uma explanação sobre os métodos "com que o artista delineia ou apresenta os seus personagens".

Dentre as enumerações de Coutinho (2008), a última corresponde mais precisamente ao que se pretende estudar no presente artigo - uma vez que este visa refletir sobre os meios característicos do gênero romântico, ilustrados tanto na delineação dos personagens, quanto na forma com que essas são expostas ao leitor.

Para tanto, é necessário pensar o personagem como um ser fictício que nasce de um ser vivo, mas não corresponde a ele (CANDIDO, 2011, p. 67), pois é criado e apresentado a partir de escolhas feitas pelo romancista. Tais escolhas constituem o arcabouço estratégico dos escritores e podem determinar se a personalidade de um personagem será descrita através de atributos físicos ou psicológicos, ou ainda se esse mesmo personagem será apresentado ao leitor por um narrador-protagonista.

Mesmo que os métodos utilizados pelo romancista sejam o aspecto mais relevante a este trabalho, é interessante também distinguir aqui a tipologia dos personagens quanto a sua importância no decorrer da estória. Para isso,utilizar-se-á a

${ }^{12}$ Cf. MOISÉS, 2012, p. 449-454, a respeito da divisão quanto à universalidade dos personagens, isto é, a distinção entre personagens planas e redondas - proposta por E. M. Forster em seu Aspects of the novel (1927). 
classificação exposta por Moisés (2012, p. 448), o qual considera a existência de "personagens principais (protagonistas) e personagens secundárias (deuteragonistas) ou/e antagônicas (antagonistas), de acordo com a importância do drama vivenciado por elas e com a perspectiva adotada pelo ficcionista”.

Segundo Candido (2011, p. 54), o personagem é um dos três elementos narrativos centrais e não pode ser desvinculado dos outros dois - o enredo e as "ideias" -, uma vez que tem a função de viver o enredo e encenar as ideias. Por conta dessa participação ativa do personagem, ele é frequentemente tomado como elemento essencial de toda narrativa. Contudo, não se pode esquecer que sem a "costura" uniforme dos três elementos, a ideia de indissociabilidade se perde e o texto tende a fracassar.

Décio de Almeida Prado (2011, p. 86), ao tratar do teatro e sua dispensável mediação de narrador, afirma que esse elemento ficcional "é uma das armas, uma das riquezas do romance, possibilitando ao autor dizer com maior clareza, se assim o desejar, aquilo que a própria trama dos acontecimentos não for capaz de exprimir”. Entre essas incapacidades de expressão factual, pode ser citada a descrição mais profunda da dor sentida pelo personagem que chora a morte de um ente querido, por exemplo. Tal descrição poderá ser feita por alguém fora da ficção (narrador heterodiegético), ou dentro dela (narrador homodiegético) - sendo classificado de autodiegético o narrador que também consista no protagonista da estória narrada - e, então, chega-se à divisão primeira e fundamental entre os tipos de narração (REUTER, 2004, p. 70-71).

Antes de continuar a classificação, é importante considerar a existência de contraste entre foco narrativo e ponto de vista. Para Aguiar (2000, p. 22),

nem sempre a análise do foco narrativo coincide com a do ponto de vista, pois naquele se impõe a descrição do relacionamento entre sujeito e objeto, digamos, entre quem vê e o que é visto; neste, se impõe um detalhamento maior da posição da voz narrativa - a voz, persona, que articula a narração, e que não coincide com o autor, mesmo numa 
narrativa autobiográfica, compondo uma espécie de máscara, alter-ego, fantasma, impresso na narração, do ser vivo que a criou.

Mesmo que se possa admitir a distinção exposta acima, as premissas utilizadas neste trabalho não fazem essa distinção sendo os dois termos, então, tomados como sinônimos.

Moisés (2012, p. 291), a partir do quadro proposto por dois críticos norte-americanos (Cleanth Brooks e Robert Penn Warren), enumera os quatro tipos de foco narrativo. $O$ primeiro ocorre quando o personagem principal narra a sua própria história (narrador-protagonista). $\mathrm{O}$ segundo, quando a história do protagonista é narrada por um personagem secundário (narradortestemunha). O terceiro foco narrativo conta com a voz narrativa em terceira pessoa de um "não-personagem", isto é, uma espécie de deus do universo ficcional, uma vez que sabe todos os acontecimentos ocorridos com os personagens em qualquer lugar e em qualquer época (narrador-onisciente). Por fim, configura o quarto tipo de foco narrativo quando a estória é contada do ponto de vista de um observador (narrador-observador), o qual, apesar da restrição óptica semelhante a do narrador-testemunha, possui um campo de observação maior - comportando "o máximo de pormenores, segundo a perspectiva em que se coloca, porém dentro dos limites de suas características pessoais" (MOISÉS, 2012, p. 295).

É importante ressaltar que, enquanto as espécies narrativas mais concisas (conto e novela) tendem a manter inalterável o foco narrativo para que o enredo não seja tumultuado, o romance possibilita a utilização de vários pontos de vista ao longo da narrativa (MOISÉS, 2012, p. 499), os quais, quando bem empregados, enriquecem a obra e amplificam as relações humanas nela expostas.

Com isso, pode-se citar ainda a distinção feita por Genette de duas ocorrências de narração, paralipse e paralepse, que dizem respeito à quantidade de informação fornecida ao leitor. A paralipse configura-se quando há "omissão de certa ação ou 
pensamento importante do herói focal, que nem o herói nem o narrador podem ignorar, mas que o narrador prefere esconder do leitor" (GENETTE, 1995, p. 207 apud DANTAS, 2006, p. 86). Já a paralepse, ao contrário da paralipse, ocorre quando o leitor recebe informação em excesso, ou seja, quando são explicitados fatos não comportados pela focalização utilizada. Para Brito (2007, p. 9), essa última estratégia pode ser considerada um "trunfo semiótico que a linguagem do cinema expunha como um dos seus procedimentos narrativos mais antiliterários", uma vez que é recorrente, no cinema, essa alternância do ponto de vista de um personagem com o de outro.

Syd Field diz, em seu Manual do Roteiro (2001, p. 11), que o roteiro cinematográfico "é uma história contada em imagens, diálogos e descrições, localizada no contexto da estrutura dramática”. Assim, é possível pensar que se o roteiro fosse um texto literário, ele se encaixaria no gênero dramático, uma vez que descreve cenários e se desenvolve a partir de diálogos com a finalidade de ser, posteriormente, representado num filme. Entretanto, não se trata de um texto a ser escrito, publicado e lido de maneira independente do filme que gerou, ou a ser produzido sem o objetivo de ir para a tela de cinema. Embora uma recente gama de publicações de roteiros famosos tenha "levado profissionais de cinema a defender a ideia de que estes constituem um novo gênero narrativo, capaz de despertar o interesse do leitor comum, não especializado" (FIGUEIREDO, 2010, p. 40), o roteiro só atinge a completude no corte final do filme - daí o seu caráter funcional e interdependente.

Em relação a sua forma contemporânea e profissional, ainda segundo Field (2001, p. 160), o roteiro é composto por (a) cabeçalho, no qual é indicada a localização (externa ou interna) e o período (dia ou noite) em que se desenvolve a sequência; (b) descrição, sempre concisa, de personagens e lugares que aparecem e da ação instaurada na sequência; e (c) diálogos. 
Algumas vezes, o roteirista sugere ao diretor a focalização de algum objeto da mise-en-scène $e^{13}$, embora isso não seja uma tarefa obrigatória. Segundo Field (2001, p. 158, grifo nosso), o escritor de roteiros "não é responsável por escrever posições de câmara e terminologia detalhada de filmagem. [...] [Seu] trabalho [...] é dizer ao diretor o que filmar, não como filmar", ou seja, é aceitável a presença de sugestões no roteiro, as quais poderão ou não ser acatadas - mas as instruções de filmagem competem apenas ao diretor.

Quanto à categorização, podem-se elencar dois tipos de roteiro: o original e o adaptado. Enquanto o primeiro nasce de uma ideia própria do roteirista, o segundo parte de um texto préexistente, que costuma ser de cunho literário. A essa prática, dá-se o nome de adaptação.

A função de quem escreve um roteiro adaptado é, justamente, adaptar o "texto-base" ao sistema filmico, ou seja, utilizar estratégias próprias da cinematografia para traduzir o conteúdo de um romance, conto, novela, ou qualquer outra espécie literária. Para tanto, toda uma equipe, que inclui o(s) roteirista(s), precisa primeiramente interpretar o conteúdo que pretende retratar no roteiro. Tal interpretação costuma gerar o descontentamento dos leitores das obras adaptadas, cuja expectativa é sempre a de que a adaptação apresente a estória da forma interpretada por eles.

Ressalta-se que os julgamentos dados às adaptações serão debatidos no presente artigo a partir das diferenças entre um romance (Dom Casmurro) e um roteiro (Capitu) - as quais serão exemplificadas por meio da análise das estratégias refletidas nesse último para a representação cinematográfica de elementos do primeiro.

Podemos tomar a imagem como o principal artifício de que se vale o cinema. Sendo assim, a caracterização de personagens cinematográficos, ao contrário dos literários, acontece por

\footnotetext{
${ }^{13}$ Termo francês derivado do teatro que denota a "organização dos objetos dentro do quadro da câmera” (EDGAR-HUNT; MARLAND; RAWLE, 2013, p. 128).
} 
excelência através da sua projeção na tela. Paulo Emílio Sales Gomes (2011, p. 110), crítico de cinema e co-roteirista de um dos objetos que regem este artigo, não nega a existência de certos personagens cinematográficos que, numa primeira instância, parecem construídos unicamente de palavras. Entretanto, o autor pontua a diferença entre personagem de romance e de cinema. Diz ele:

\begin{abstract}
A personagem de romance afinal é feita exclusivamente de palavras escritas, e já vimos que mesmo nos casos minoritários e extremos em que a palavra falada no cinema tem papel preponderante na constituição de uma personagem, a cristalização definitiva desta fica condicionada a um contexto visual (GOMES, 2011, p. 111).
\end{abstract}

Ao contrário do personagem literário, o qual "pode não chegar inteiro ao leitor" (CARRERO, 2005, p. 256) - fazendo com que esse tenha liberdade para imaginá-lo -, o personagem de cinema, até o final da película, é desmascarado por completo e aparece inteiro diante dos espectadores, não admitindo que esses o encarem de outro modo (MOISÉS, 2012, p. 535).

Tendo em vista as formas de apresentação dos personagens cinematográficos, pode-se pensar a figura do narrador como uma importante estratégia do cinema. Segundo Gomes (2011, p. 107), a narração em câmera objetiva - em que o narrador-câmera não "se impõe", mas apenas exibe as ações seguindo o ponto de vista ora deste, ora daquele personagem - essa narração costuma ser mais utilizada. Contudo, há casos em que o narrador desenvolve todo o enredo a partir da perspectiva de um único personagem, ou seja, mostra exclusivamente o que esse personagem está vendo, fazendo, sentindo, etc.

Vale ressaltar que, ao contrário do personagem romanesco cujo perfil psicológico pode ser expresso de forma irrestrita no romance -, o personagem cinematográfico é mais facilmente representado pelos seus atributos físicos, sendo a reprodução da 
40 | Danielle Rasmussen Betemps

consciência de um personagem mais limitada em um filme do que em um texto literário de qualquer espécie.

A narração no cinema ocorre por meio de um "instrumental mecânico [a câmera] através do qual o narrador se exprime” (GOMES, 2011, p. 107, grifo nosso). A partir daí, esse narrador poderá assumir o ponto de vista físico ora deste, ora daquele personagem e, também, o ponto de vista intelectual de diversos personagens sucessivamente.

Portanto, é de suma importância distinguir as duas descrições possiveis de planos cinematográficos, ou seja, os dois tipos de "olhos" narradores: o plano objetivo constitui a maioria dos planos e pode ser equiparado ao narrador literário em terceira pessoa (onisciente e onipresente), dada a sua capacidade de mostrar "coisas ao espectador de uma forma 'impossível', dando a ele uma visão dos eventos que está testemunhando como se fosse Deus" (EDGAR-HUNT; MARLAND; RAWLE, 2013, p. 121); e o plano subjetivo retrata o mundo a partir da visão única de um personagem (ou objeto) da mise-en-scène, ou seja, são os olhos da "câmera em primeira pessoa” (EDGAR-HUNT; MARLAND; RAWLE, 2013, p. 121).

Outra classificação a ser considerada é a que enfoca não a visão, mas a fala, ou seja, a "voz" de quem narra. Essa classificação, apresentada por Edgar-Hunt, Marland e Rawle (2013), possui três espécies de narração em filmes: extradiegética, homodiegética e intradiegética.

A primeira, extradiegética, corresponde à narração de uma voz que o espectador não reconhece - seja por se tratar de um personagem que ainda não foi apresentado, ou por essa voz sequer pertencer a um personagem do filme. Um exemplo para essa primeira espécie pode ser a narração exterior na introdução de $\mathrm{O}$ Estranho Mundo de Jack ${ }^{14}$.

${ }^{14}$ O ESTRANHO mundo de Jack. Direção: Henry Selick. Produção: Tim Burton, Jeffrey Katzenberg e Danny Elfman. Intérpretes: Danny Elfman; Chris Sarandon; Catherine O'Hara; William Hickey; Paul Reubens e outros. Roteiro: Tim Burton e Caroline Thompson. Gênero: Animação. [S.1.]: Buena Vista, 1993. 1 DVD (76 min), NTSC, son., color. Título original: The nightmare before Christmas. 
A narração homodiegética retoma a classificação de narradorprotagonista do romance e, por se tratar de cinema, abre espaço também para um personagem que queira estabelecer contato visual com a câmera e consequentemente com o espectador - o que é um caso raro, mas pode ser exemplificado pelos monólogos do protagonista Alfie em Alfie - O Sedutor ${ }^{15}$.

Por fim, a narração intradiegética na qual se tem dois ou mais personagens conversando a fim de fazer avançar a narrativa. Por exemplo: um personagem deixa sua fala incompleta para que ela seja, a seguir, completada por outro personagem - essa estratégia simbólica ocorre entre os personagens Marianne e Ferdinand, em O Demônio das Onze Horas ${ }^{16}$, e serve para ilustrar essa última espécie de narração cinematográfica.

O roteiro Capitu parte da cerimônia nupcial de Bento e Capitolina até o momento em que decidem a separação, sendo utilizadas analepses (grosso modo, flashbacks) - em função das quais algumas ações do passado revezam-se com as do presente - para apresentar acontecimentos marcantes na vida do casal.

Em relação ao estilo de escrita do roteiro, esse - por ter uma profissional da literatura como co-roteirista (Lygia Fagundes Telles) - apresenta, principalmente nas descrições, estruturas romanceadas que demonstram o cuidado dos roteiristas na ilustração das ações internas e externas dos personagens.

Um dos traços importantes reconhecidos em Capitu é a utilização de um narrador-câmera que segue unicamente os passos do personagem Bentinho. Ao optarem por essa forma de narrar, os roteiristas "escondem" as perspectivas das outras figuras do enredo e deixam o espectador sob a influência de uma única visão.

${ }^{15}$ ALFIE - O Sedutor. Direção: Charles Shyer. Produção: Elaine Pope e Charles Shyer. Intérpretes: Jude Law; Marisa Tomei; Susan Sarandon; Nia Long; Omar Epps e outros. Roteiro: Bill Naughton, Elaine Pope e Charles Shyer. [S.1.]: Paramount, 2004. 1 DVD (105 min), NTSC, son., color. Título original: Alfie.

${ }^{16}$ O DEMÔNIO das Onze Horas. Direção: Jean-Luc Godard. Produção: Georges de Beauregard. Intérpretes: Jean-Paul Belmondo; Anna Karina e outros. Roteiro: Jean-Luc Godard. [S.1.]: Cult Classic, 1965. 1 DVD (115 min), NTSC, son., color. Título original: Pierrot le fou. 
Assim, tanto a maneira como são delineados os personagens no filme, quanto a função desempenhada por um narradorprotagonista no cinema, possibilitam a reflexão acerca das diferenças entre romance e roteiro.

O primeiro fator relevante identificado no início do roteiro foi a quebra da linearidade proposta no romance. Dom Casmurro rememora acontecimentos que partem da sua infância e se estendem até a morte de Ezequiel. Sendo assim, o roteiro condensa o texto literário e o adapta ao sistema cinematográfico - e, para isso, desloca os personagens para um presente, iniciado no casamento de Bentinho e Capitu e diferente no romance, e vale-se de analepses ao longo do texto a fim de remontar o passado. Em outras palavras, os roteiristas utilizam uma "ferramenta" cinematográfica para encaixar a complexidade e extensão do romance na sucinta forma de um roteiro.

Além da condensação e da consequente supressão de certas informações do romance, a transposição também apresenta acréscimos, os quais representam a liberdade de criação dos roteiristas e o desapego à ideia de fidelidade em seu nível mais rígido. As evidentes adições pensadas por Lygia e Paulo Emílio serão elencadas e analisadas a partir de agora.

Pode-se dizer que a primeira delas foi influenciada pela necessidade de condensação exposta acima. Trata-se da inserção do quintal da casa dos recém-casados (na Tijuca) como ambiente no qual Capitu e Bentinho exteriorizam o sentimento nostálgico que os consome na primeira semana de casamento. No roteiro são expostos diálogos nos quais os personagens recordam acontecimentos de quando eram adolescentes (TELLES; GOMES, 2008, p. 11-19). No romance, a ideia referida pelos roteiristas pode ser identificada nesta passagem:

De quando em quando, tornávamos ao passado e divertíamo-nos em relembrar as nossas tristezas e calamidades, mas isso mesmo era um modo de não sairmos de nós. Assim vivemos novamente a nossa longa espera de namorados, os anos da adolescência, a denúncia que está nos primeiros capítulos, e ríamos de José Dias, que 
conspirou a nossa desunião e acabou festejando o nosso consórcio. (ASSIS, 2011, p. 194).

A nostalgia da primeira semana de casamento está situada no romance, mas sem o contexto (passeio do casal pelo quintal da casa) exposto no roteiro. Para confirmar esse acréscimo, podemos observar a importância do ambiente na transposição de uma das recordações de Bentinho:

BENTINHO (Endireitando o corpo e tentando ver ainda a cobrinha que desapareceu na moita.) Lembra, sim, lembra o José Dias! (Contém o riso. Fica pensativo.) Aquele mesmo jeito de aparecer e sumir tão silenciosamente depois de armar suas conspirações, é claro. Ah, Capitu, o ódio que tive dele naquela tarde, quando percebi seu jogo para nos separar. E mamãe tão inocente, aprovando. (TELLES; GOMES, 2008, p. 13, grifo dos autores).

Outro elemento adicionado no roteiro diz respeito à gestação de Capitu. No romance, o narrador apenas alude ao acontecimento, como pode ser observado no trecho:

Os pais [Escobar e Sancha], como os outros pais, contavam as travessuras e agudezas da menina, e nós, quando voltávamos à noite para a Glória, vínhamos suspirando as nossas invejas, e pedindo mentalmente ao céu que no-las matasse...

...As invejas morreram, as esperanças nasceram, e não tardou que viesse ao mundo o fruto delas. Não era escasso nem feio, como eu já pedia, mas um rapagão robusto e lindo.

A minha alegria quando ele nasceu não sei dizê-la; nunca a tive igual [...]. (ASSIS, 2011, p. 201).

Percebe-se no trecho acima que o narrador-protagonista salta do seu desejo, compartilhado com a esposa, de ter um filho para o nascimento da criança, ou seja, a narração não comporta o período de gestação de Capitu. Já o roteiro, expõe tanto o anúncio da 


\section{4 | Danielle Rasmussen Betemps}

gravidez - feito pela mulher após o retorno conturbado de um baile $^{17}$-, quanto alguns momentos da gestação de Capitu e até da amamentação da criança:

BENTINHO Logo hoje, por quê?

CAPITU Porque justamente hoje eu tinha resolvido the contar... (Faz uma pausa. A respiração fica mais forte. Entrelaça as mãos no colo e levanta a cabeça. Encara o marido.) Vamos ter um filho. (TELLES; GOMES, 2008, p. 58, grifo dos autores).

Capitu está de pé e de costas para a janela aberta. Tem um xale nos ombros e os braços cruzados. Puxa nas mãos as pontas do xale com as franjas que descem até quase seu ventre avolumado. (TELLES; GOMES, 2008, p. 59, grifo nosso).

Piquenique no campo. Uma tarde de verão. $\mathrm{O}$ lago. $\mathrm{O}$ pequeno bosque mais distante. [...] Recostada no tronco da árvore, está Capitu sentada, amamentando a criança. Cobriu o peito com um lenço rendado e ali se deixou ficar quieta, vendo a criança mamar. (TELLES; GOMES, 2008, p. 67-68).

Fica evidente a opção dos roteiristas por ilustrar a passagem de tempo suprimida no romance e, concomitantemente, interpolála com outros acontecimentos citados pelo narrador literário como, por exemplo, a referência às dez libras economizadas por Capitu $^{18}$.

${ }^{17} \mathrm{O}$ roteiro remete a um elemento do livro: Bentinho fica enciumado ao ver Capitu com os braços despidos durante um baile (ASSIS, 2011, p. 196-197). O roteiro insere um momento em que os dois estão no quarto, após retornarem do referido baile, e Bentinho comunica à esposa que seus braços despidos não o agradaram (TELLES; GOMES, 2008, p. 55-57).

${ }^{18}$ No romance, a exposição ocorre antes da gravidez (ASSIS, 2011, p. 198-199), enquanto no roteiro Capitu já está grávida e sugere inclusive gastar as economias no enxoval do filho (TELLES; GOMES, 2008, p. 61-64). 
O cacoete do personagem secundário Escobar constituiu outra escolha expressiva para o processo de transformação do romance em roteiro. Observemos, nos trechos abaixo, como Escobar é caracterizado pelos narradores literário e cinematográfico:

Chamava-se Ezequiel de Sousa Escobar. Era um rapaz esbelto, olhos claros, um pouco fugitivos, como as mãos, como os pés, como a fala, como tudo. Quem não estivesse acostumado com ele podia acaso sentir-se mal, não sabendo por onde lhe pegasse. [...] O sorriso era instantâneo, mas também ria folgado e largo. [...] Era mais velho que eu três anos [...] Aqueles modos fugitivos cessavam quando ele queria, e o meio e o tempo os fizeram mais pousados. (ASSIS, 2011, p. 134-135, grifo nosso).

Escobar inclina-se e leva a mão direita à boca, passando de leve as pontas dos dedos no lábio inferior, como se quisesse estudar-lhe o contorno. Prende o lábio entre o polegar e o dedo médio, o indicador batendo ligeirissimamente na pequena prega formada pelo lábio. Esse cacoete é antigo. Quando não está distraído, procura combatê-lo: algumas vezes, recolhe a mão em meio do gesto, disfarça. [...] Devido ao seu talhe espigado e à jovialidade dos seus gestos e roupas, aparenta ser mais moço do que Bentinho. Tem cabelos ondulados, olhos claros e riso fácil. (TELLES; GOMES, 2008, p. 32-34, grifo nosso).

Poucas diferenças e muitas semelhanças podem ser reconhecidas na exposição do personagem Escobar nas duas obras. Entretanto, o aspecto mais divergente é justamente também o mais cinematográfico: a ação de levantar as pontas dos dedos para contornar os lábios é um fator pontual e, portanto, mais imagético do que os "modos fugitivos" dos pés e das mãos salientados no romance.

A transformação do cacoete é também crucial para o desenvolvimento do roteiro, pois assim como o "jeito dos pés de Escobar” (TELLES; GOMES, 2008, p. 82), o menino Ezequiel 
também será repreendido por imitar esse contornar dos lábios com as pontas dos dedos:

Inclinando-se para o filho, Capitu fica a observá-lo. O menino continua vendo as gravuras do álbum, a mão direita na boca, ou melhor, as pontas dos dedos acariciando os lábios.

CAPITU (Baixando-lhe a mão com certa energia.) Tira a mão da boca, Ezequiel! (TELLES; GOMES, 2008, p. 79, grifo dos autores).

Outra transformação feita pelos roteiristas, a qual também reflete essa busca pela melhor expressão cinematográfica de elementos literários, ocorre no enterro do personagem Escobar. Vejamos como é ilustrada essa passagem no romance e no roteiro:

As minhas [lágrimas] cessaram logo. Fiquei a ver as dela; Capitu enxugou-as depressa, olhando a furto para a gente que estava na sala. Redobrou de carícias para a amiga [Sancha], e quis levá-la; mas o cadáver parece que a retinha também. Momento houve em que os olhos de Capitu fitaram o defunto, quais os da viúva, sem o pranto nem palavras desta, mas grandes e abertos, como a vaga do mar lá fora, como se quisesse tragar também o nadador da manhã. (ASSIS, 2011, p. 220-221, grifo nosso).

Bentinho aproxima-se. Vemos seu olhar tristíssimo estender-se sobre o morto e de repente fixar-se em alguma coisa. A câmera, que também vai acompanhando esse olhar, pára e se fixa nesse outro alvo: duas mãos de mulher estão fortemente agarradas às bordas do caixão, como que impedindo que o levem. [...] E aquelas mãos muito brancas, crispadas sobre o negrume dos punhos do vestido, puxando o caixão para que os outros não o arrebatem. $O$ olhar de Bentinho começa a subir pelas mangas negras do vestido até encontrar a dona daquelas mãos. Então o seu olhar se detém, estupefato: pois essas mãos nas bordas do esquife estão de tal maneira próximas e iguais, bem como iguais as mangas do vestido, mas tão iguais, que a idéia inicial só 
podia ser esta, as mãos pertencem a uma só pessoa, Sancha. No entanto, é a mão esquerda de Capitu que se agarra ao caixão com o mesmo desespero com que a mão direita da viúva também o segura no instante em que se preparam para levá-lo. (TELLES; GOMES, 2008, p. 132, grifo nosso).

Percebe-se, então, a substituição dos "olhos" pelas "mãos" de Capitu, ou seja, a tensão provocada pelo momento no romance é mantida no roteiro, mas o seu componente principal é alterado.

Em relação aos narradores das duas obras, sabe-se que Dom Casmurro apresenta um narrador em primeira pessoa e protagonista da estória que conta. Toda a narração é estruturada conforme sua visão, seu ponto de vista. Isso faz com que a narrativa obtenha ambiguidade no que tange ao verdadeiro caráter da personagem Capitu, pois o simples fato de Bentinho desconfiar da mulher e ressaltar aspectos que, aos seus olhos, o levam a crer na infidelidade de Capitu, não é suficiente para condenar, nem inocentar a personagem feminina. $\mathrm{O}$ narrador conta apenas o que vê e mesmo assim o leitor é incapaz de ter plena confiança na saúde dessa visão. Assim, Bentinho (ou melhor, Machado) deixa nas mãos do leitor a tarefa de completar, ou legitimar, essa lacuna.

O roteiro de Lygia e Paulo Emílio, apesar de levar no título o nome da personagem Capitu, contém marcações que remetem ao uso de uma câmera objetiva que segue apenas os passos do protagonista Bentinho. Além disso, todo o ponto de vista de Bentinho expresso no romance é mantido em Capitu - incluindo seus ciúmes e dúvidas, bem como o mal-estar sofrido por ele em virtude da suposta infidelidade da mulher.

Entretanto, é possivel identificar uma ocorrência de paralepse no roteiro:

O final da frase acaba por se perder no corredor onde ambos desaparecem. Capitu afasta-se para dar alguma ordem ao copeiro, que não se vê, ouve-se apenas quando ela chama discretamente, Domingos! Sancha faz sua ronda pela sala, percorrendo com curiosidade os quadros meio mergulhados na penumbra. Detém-se de repente no teto 
onde estão pintadas guirlandas, arrepanhadas de espaço em espaço por pequenas andorinhas azuis. Toma nas mãos uma estatueta de porcelana. (TELLES; GOMES, 2008, p. 36).

Antes da introdução acima, o personagem Bentinho já havia se retirado da sala na companhia de Escobar, deixando sozinhas Capitu e Sancha, as quais iniciaram um diálogo de sete páginas, do qual o protagonista não participa. Assim, os roteiristas expõem uma informação que vai além do personagem Bentinho, ou seja, rompem com a focalização escolhida para ser majoritária e a direcionam para Capitu.

Por se tratar de um recurso comum e aceitável no cinema, a ocorrência não pode ser vista como incoerente, ou infiel ao narrador do romance, o qual está preso à lógica exigida pelo tipo de discurso que lhe dá forma: o verbal. Diferentemente de um texto literário, a matéria-prima do cinema é a imagem visual, cuja expressão torna o elemento verbal secundário e o faz desde o roteiro.

Apesar de o roteiro ter sido considerado um elemento indissociável do filme que o incorpora, o presente artigo propôs analisar unicamente o conteúdo de Capitu, desconsiderando a versão final da obra, concretizada no filme homônimo. Partiu-se da ideia de que o roteiro é suficiente para alcançar o objetivo principal deste trabalho, qual seja: ilustrar os aspectos similares e convergentes entre dois tipos textuais (literário e cinematográfico) na configuração de dois elementos ficcionais (personagem e narrador). Por exemplo: como ocorre em um texto literário, a simples leitura do roteiro possibilitou a identificação e o estudo do seu foco narrativo, independentemente do ponto de vista da câmera ter sido objetivo ou subjetivo no filme.

A partir do referencial estudado, foi possivel perceber que, não só os adaptadores (roteiristas, cineastas, etc.) fazem escolhas supressões, inserções, transformações; também os escritores (contistas, novelistas, romancistas, etc.) optam pelos métodos a 
serem utilizados, suprimem personagens, inserem diálogos, transformam o tempo.

A conclusão que se chega é que as escolhas caracterizam tanto o fazer literário quanto o cinematográfico, pois, em geral, é a adaptação que está presente nesses dois sistemas, movendo-os constantemente. Antes dos escritores de Capitu terem optado pela focalização no personagem principal do romance, o escritor de Dom Casmurro optou pela utilização de um narrador-protagonista. E isso também ocorreu com o cineasta Paulo César Saraceni, o qual, para filmar Capitu, teve que adaptar o roteiro de Paulo Emílio Sales Gomes e Lygia Fagundes Telles.

A exposição dos acréscimos elencados do roteiro analisado possibilitou o reconhecimento do caráter funcional desse gênero textual. Ao contrário de um texto literário, que visa à narração de uma estória para ser lida posteriormente, o roteiro cinematográfico tem, majoritariamente, o objetivo de ser filmado, editado e projetado. Por conta disso, deve atender aos requisitos da maneira filmica de fazer ficção, os quais não correspondem à maneira literária de fazê-lo.

Com a confrontação dos dois textos analisados, pôde-se comprovar a inaplicabilidade da ideia de fidelidade entre duas obras comportadas por sistemas de signos diferentes. $\bigcirc$ roteiro adaptado só poderá ser fiel ao romance que adapta quando desconsiderar suas próprias características - o que é sistematicamente impossivel.

Concluiu-se, então, que as adaptações cinematográficas não devem ser concebidas como inferiores em virtude dos meios que possuem para se expressar. Literatura e cinema são duas manifestações artísticas diferentes, cujos "apreciadores" têm nomes diferentes (o leitor da primeira e o espectador do segundo), e que, por fim, possuem linguagens diferentes, a partir das quais originam experiências estéticas também diferentes. 
50 | Danielle Rasmussen Betemps

\section{Referências}

ASSIS, Machado de. Dom Casmurro. Porto Alegre: L\&PM, 2011. (Coleção L\&PM POCKET).

AVELLAR, José Carlos. O chão da palavra. Rio de Janeiro: Rocco, 2007.

BAZIN, André. O Cinema: Ensaios. São Paulo: Brasiliense, 1991.

BENJAMIN, Walter. A obra de arte na era de sua reprodutibilidade técnica. In: _____. Magia e técnica, arte e política. São Paulo: Brasiliense, 1986. p. 165-196.

BRITO, João Batista de. $\mathrm{O}$ ponto de vista em cinema. Graphos, João Pessoa, v. 9, n. 1, p. 7-12, jan./jul. 2007. Disponível em: $<$ http://periodicos.ufpb.br/ojs2/index.php/ graphos/article/view/4706/3570>. Acesso em: 19 jan. 2014.

CANDIDO, Antonio et al. A personagem de ficção. 12. ed. São Paulo: Perspectiva, 2011.

CARRERO, Raimundo. Os segredos da ficção. Rio de Janeiro: Agir, 2005.

COUTINHO, Afrânio. Gênero de ficção. In: . Notas de teoria literária. Rio de Janeiro: Vozes, 2008.

DANTAS, Geyzon Bezerra. O Cobrador, Maiakovsky, Máiquel e o dentista. Graphos, João Pessoa, v. 8, n. 1, p. 81-88, jan./jul. 2006. Disponivel em: <http://periodicos.ufpb.br/ojs/index.php/graphos/article/viewFil e/9314/4995>. Acesso em: 19 jan. 2014.

DINIZ, Thaís Flores Nogueira. Tradução intersemiótica: do texto para a tela. Cadernos de Tradução, Florianópolis, v. 1, n. 3, p. 
Mesmo que Capitu tenha traído Dom Casmurro | 51

313-338, 1998. Disponível em: <https://periodicos.ufsc.br/index.php/traducao/article/view/539 0/4934>. Acesso em: 18 jan. 2014.

EDGAR-HUNT, Robert; MARLAND, John; RAWLE, Steven. A linguagem do cinema. Porto Alegre: Bookman, 2013.

FIELD, Syd. Manual do roteiro: os fundamentos do texto cinematográfico. 14. ed. Rio de Janeiro: Objetiva, 2001.

FIGUEIREDO, Vera Lúcia Follain de. Narrativas migrantes: literatura, roteiro e cinema. Rio de Janeiro: 7Letras, 2010.

GENETTE, Gerard. Palimpsestos: la literatura en segundo grado. Madrid: $\quad$ Taurus, $1989 . \quad$ Disponivel em: <http://historiaiuna.com.ar/wp-content/material/2012_ genette_palimpsestos.pdf $>$. Acesso em: 18 jan. 2014.

GOMES, Paulo Emílio Sales et al. A personagem de ficção. 12. ed. São Paulo: Perspectiva, 2011.

JOHNSON, Randal et al. Literatura, cinema e televisão. São Paulo: Editora Senac São Paulo - Instituto Itaú Cultural, 2003.

METZ, Christian. A significação no cinema. São Paulo: Perspectiva, 2010.

MOISÉS, Massaud. A criação literária. São Paulo: Cultrix, 2012.

PAECH, Joachim. Os sons e as imagens em Brinkmanns Zorn. In: MÜLLER, Adalberto; SCAMPARINI, Julia (Org.). Muito além da adaptação: literatura, cinema e outras artes. Rio de Janeiro: 7Letras, 2013. p. 51-66.

PLAZA, Julio. Tradução Intersemiótica. 2. ed. São Paulo: Perspectiva, 2010. 
PRADO, Décio de Almeida et al. A personagem de ficção. 12. ed. São Paulo: Perspectiva, 2011.

REUTER, Yves. Introdução à análise do romance. 2. ed. São Paulo: Martins Fontes, 2004.

STAM, Robert. Teoria e prática da adaptação: da fidelidade à intertextualidade. Ilha do Desterro, Florianópolis, n. 51, p. 19-53, jul./dez. 2006.

TELlES, Lygia Fagundes; GOMES, Paulo Emílio Sales. Capitu. 2. ed. São Paulo: Cosac Naify, 2008.

Recebido em 06 de abril de 2017.

Aprovado em 05 de julho de 2017. 